\title{
ANALYSIS OF THE FACTORS THAT DETERMINE THE FEATURES OF THE ORGANIZATION OF PUBLIC-PRIVATE PARTNERSHIP IN THE INNOVATION ACTIVITY OF UKRAINE
}

\author{
Oleh Holovko', Liudmyla Sakevych ${ }^{2}$
}

\begin{abstract}
The objective of the article is to clarify the nature and benefits of public-private partnership and analysis of factors influencing its organization and dissemination in innovation. The usefulness of introducing public-private partnership in the innovation sphere is due to the possibility of combining state regulation of innovation development with the potential of private business, which should be considered as a carrier of managerial, human, and financial capital. Society is interested in the organization of public-private partnership in innovation because the result of achieving its strategic goal would solve several socially important problems, which include employment growth, increasing real incomes, spreading innovation, and accelerating socioeconomic progress. Methodology. During the analysis, public-private partnership was considered as a complex open system with the use of systematic analysis methodology in the study, which allowed to emphasize certain aspects of the specific nature of its operation. Results. Public-private partnership in innovation is a form of relationship that arises between the public sector and private business on a medium- or long-term basis and involves the creation of innovation infrastructure, production, and distribution of innovation products on mutually beneficial terms, which is achieved by providing a specific form financing, the common interests of the participants and the distribution of possible risks between them. The organization of public-private partnership, especially in the field of innovation, is influenced by a significant number of factors among which it is useful to outline institutional, legislative, economic, internal, and external, direct, and indirect. The institutional factor determines the nature of institutional policy that affects public-private partnerships. Legislative factors provide for legal regulation of the establishment and further operation of public-private partnership in the field of innovation. The economic factors influencing the organization of public-private partnership include credit, tax (tax holidays, reduction of income tax rates, tax credit), investment and depreciation (reduction of depreciation, increase of depreciation rates) policy. Practical implications. As a result of the analysis, several benefits that both the public sector and private business receive from the spread of public-private partnerships in innovation are outlined. The reflection of institutional, legislative, economic, and other factors of the organization of public-private partnership will allow to consider their influence for the intensification of innovative activity as a basis for increasing the competitiveness of the national economy. Value/originality. The use of systematic analysis allowed to outline the main factors that contribute or conversely the spread of public-private partnership in innovation in Ukraine. Considering their action will minimize the negative manifestations and make full use of the positive aspects, which will be an important factor in enhancing innovative growth on the basis of public-private partnership. Economic and other factors of public-private partnership will allow to take into account their impact to enhance innovation as a basis for increasing the competitiveness of the national economy.
\end{abstract}

Key words: public-private partnership, innovation, national economy, incentives, organization of concession agreements.

JEL Classification: L32, O30

\footnotetext{
Corresponding author:

${ }^{1}$ Black Sea Research Institute of Economy and Innovation, Ukraine.

E-mail: o.p.golovko@gmail.com

ORCID: https://orcid.org/0000-0002-6813-6735

${ }^{2}$ Black Sea Research Institute of Economics and Innovation, Ukraine.
} 


\section{Introduction}

The realities of modern economic development require a constant increase in production output, growth of productivity, the emergence of modernized goods and services endowed with new qualities and properties. One of the ways to achieve such changes is to intensify innovation and dissemination of knowledge, more intensive research, and development of new technologies. An important step in solving this problem is the combination of state regulation of innovation development with market levers.

A promising direction for the growth of innovation is its organization on the basis of public-private partnership. This model of building relationships allows to ensure a balance between private and public interests, increase the amount of investment resources involved, and to promote the effective functioning of innovative entrepreneurship and the innovative market as a whole.

The organization of public-private partnership fundamentally changes the functions of the state. After all, it becomes an equal partner along with private business, with which it distributes risks and profits. Therefore, in such relations, the state no longer acts as a subject of power that performs regulatory functions. In contrast, it receives several benefits which include the ability to solve several socio-economic problems and implement important innovative project which are the basis for strengthening the position of the Ukrainian economy on the world stage. For businesses, participation in public-private partnerships also brings numerous benefits: obtaining government benefits (lower tax rates, easing regulatory restrictions, etc.) and access to public funding.

Thus, the partnership between business and the state should be considered as a special type of relationship, the specificity of which is due to the spread of equal rights for both participants, allowing for various infrastructure projects and associated with the efficiency of investment, management, and economic activities. In such partnerships special priority is given to achieving the strategic goals of the country, so the spread of public-private partnership is played by all stakeholders: business, state, society. We believe that such positive aspects of public-private partnership should be a strong argument for its dissemination in the innovation activities of Ukraine.

\section{General principles of public-private partnership in innovation}

The problem of public-private partnership development in innovation is extremely important for Ukraine, as the recently implemented state policy in the field of science and innovation cannot be defined as effective. Active state intervention in the innovation process was unsuccessful due to the failure to solve several problems, primarily the availability of resources, and significantly restrained market competition in the field of innovation. On the other hand, domestic business remains quite passive to innovative development. Thus, in 2019, the share of innovatively active industrial enterprises in their total number was only $15.8 \%$ (State Statistics Service of Ukraine, 2020), which is one of the lowest rates since 2011. That is why the urgent task for Ukrainian society is to intensify the development of public-private partnership in innovation.

Several advantages of public-private partnership have become the basis for the widespread use of the term "public-private partnership", which is considered today in the economic, social, and legal domain. Such principles significantly complicate its unambiguous understanding, which led to a lack of systematization in its definition.

Quite a broad understanding is presented by H.M. Rozum, according to which public-private partnership is "an institutional and organizational alliance between the state and business in order to implement socially significant projects and programs in a wide range of industries and in the field of innovation" (Rozum, 2017) and V. H. Varnavskyi, who suggests that publicprivate partnership acts as "an institutional and organizational alliance between the state and business to implement national and international projects in industry, research and development, public services (Varnavskyi, 2005). According to such definitions, public-private partnership can be applied to a wide range of industries. In Ukraine, there is a significant interest in the implementation of such projects in energy and road construction. But, in our opinion, the partnership can be most successful in regulating the innovation activities of the national economy.

Public-private partnership in the innovation sphere is defined as institutional, organizational, and financial interaction of public authorities, municipal governments, and private business, aimed at joint implementation of innovation 
projects and mutual support at all stages of the innovation process (Mihai, 2020). Since publicprivate partnership is based on property relations and an important area of its activity is to increase ownership, then public-private partnership should be considered as a mutually beneficial mediumor long-term property management relationship, which involves placing private business resources in the plane of strategically important objects of state functioning, which is necessary for the development of innovation.

Analysis of existing interpretations of this concept allows us to define public-private partnership in innovation as a form of relationship that arises between the public sector and private business on a medium or long term and involves the creation of innovation infrastructure, production and distribution of innovation products on mutually beneficial terms, which is achieved by providing a specific form of funding, the common interests of participants and the distribution of possible risks between them.

Thus, the proposed definition gives grounds to outline four key features of public-private partnership, including in innovation:

1) ability to manage the main attributes of property rights - possession, disposal, use;

2) creation of a favourable investment and innovation environment, which serves as a basis for the organization and operation of competitive infrastructure facilities;

3) pooling of financial, organizational, human and other resources that are in private and state ownership to perform socially necessary activities;

4) institutional allocation and regulation of interests as a result of the spread of public-private partnership.

In general, the interaction of the state and the private sector in innovation involves the distribution of roles, as a result of which the main tasks of the state are to promote the emergence and dissemination of fundamental knowledge and necessary technologies, development of innovation infrastructure and formation of institutional foundation to support innovative enterprises. In turn, the business is committed to finding new knowledge and advancing innovative technologies, research and development of innovative products based on their own research and their further market development, provides effective management and support to achieve the goals.

\section{Factors influencing the organization of public-private partnership in the field of innovation}

The organization of public-private partnership, especially in the field of innovation, is influenced by many factors, among which it is appropriate to outline institutional, legislative, economic, internal and external, direct and indirect.

The institutional factor determines the nature of institutional policy, which affects the publicprivate partnership in innovation. Most European countries at the national level encourage the creation of various funds to support publicprivate partnerships, which is the basis for raising awareness of both business and public authorities on the organization of concessions in innovation. In addition, an important goal of such funds is to advise on the positive consequences of the implementation of joint innovation projects.

Legislative factors influencing the public-private partnership in the innovation sphere provide for legal regulation on the establishment and further operation of associations. Today, the practice of organizing various committees at the state or regional level to promote the development of public-private partnerships in innovation is becoming quite common. In most cases, they act as separate administrative units, the activities of which are aimed at increasing the number of concession agreements due to increasing the number of implemented innovative projects. We believe that the legislative factor is one of the basic factors in stimulating innovation on the basis of public-private partnership, as it allows to clarify the rules of partnership, the degree of responsibility and obligations of the parties.

It should be noted that in Ukraine the regulation of public-private partnership is carried out in accordance with the Law of Ukraine "On PublicPrivate Partnership", which was adopted in 2010. In this legislative act in Art. 4 lists the areas of public-private partnership (Law of Ukraine, 2010), in which there is no mention of scientific and technical projects or innovative technologies. This suggests that at the time that the law was passed, the state was not interested in stimulating the development of innovation.

Economic factors include credit, tax, investment, and depreciation policies. In particular, the credit policy allows to establish the relationship between the number of loans received for the organization of innovation and the number of implemented 
projects. It is clear that a larger share of loans will allow entrepreneurs to implement and implement more innovative solutions, which is why credit policy should be defined as one of the important in the organization of public-private partnership in the field of innovation.

A special place in stimulating innovation on the basis of public-private partnership is occupied by tax policy, within which there are two areas that are directly aimed at innovation, namely: "granting certain tax benefits due to the implementation of innovative projects or activities of innovative enterprises, and the creation of special tax regimes to support innovation in technology parks" (Danilov, 2009). One of the most common mechanisms for providing tax benefits is a tax holiday, which provides an exemption of the entity from payment of income tax for a certain period. It has been shown that this step makes it possible to "reduce the tax burden on taxpayers and free up certain resources for development" (Marchenko, Tkachenko, 2003). Such a tool for tax incentives for innovation has become widespread in France, Hungary, and Macedonia.

Providing tax holidays to stimulate innovationbased public-private partnership can be implemented in such areas as:

- tax support of public-private partnership in the innovation sphere. In this case, the benefit is provided only to those partnerships whose purpose is to develop the innovation sphere and also set certain restrictions that clearly define the articles of intended use of the released funds, as a result of obtaining the benefit;

- temporary withdrawal from taxation of profits from the implementation of innovative projects.

Another tool of tax policy to stimulate innovation on the basis of public-private partnership is the reduction of income tax rates, which has two principles. First, the reduction of income tax rates from the implementation of innovative projects. A characteristic feature is that the reduction of the tax rate is applied only to the profit received as a result of the implementation ofinnovative projects. Therefore, the need for separate tax accounting of costs and implementation of an innovative project is determined, which significantly complicates accounting. Second, the reduction of tax rates for innovative enterprises. However, such a mechanism requires a clear definition of the criteria for defining the subjects subject to preferential taxation and justification of the appropriate period and the size of the tax rate reduction. The most practical application of such a tool was in France, Greece, and Turkey. In the latter there is a practice of complete exemption from taxation of profits of enterprises engaged in research (Ivanov, 2007).

In Ireland, Spain, Canada, Luxembourg, Slovakia, the United States, Turkey, and France, such a tax policy instrument for stimulating the development of innovation as a tax credit, which has two forms, has become widespread. The first method is to reduce the amount of income tax on the share of total innovation costs. The second is incremental, the essence of which is to reduce the amount of tax liabilities of the enterprise by part of the excess of innovation costs in the reporting period compared to the previous tax period. Typically, the latter tool is used to intensify innovation and encourage businesses to increase innovation costs. Thus, the incremental tax credit is one of the important factors in the growth of investment in research and development.

While analysing the impact of state tax policy on the growth of innovation, including on the basis of public-private partnership, it is appropriate to recognize that it should be based on two principles: 1) only the targeted use of financial resources stored in the enterprise as a result of obtaining tax benefits;

2) application of the preferential taxation procedure only for solving innovative tasks that are a national priority.

Depreciation policy is very important for Ukraine, as according to various estimates, the depreciation of the main factors of production at state-owned enterprises ranges from $40 \%$ to $65 \%$. Such circumstances necessitate the modernization and renewal of the technical and technological base, which will be the basis for economic growth. That is why public-private partnerships help to attract new equipment owned by private businesses. Quite a radically different situation is found in developed countries, where the degree of depreciation of fixed capital is not so significant. Accordingly, public-private partnership is widespread in the field of intangible production, namely education, science, medicine.

In addition, accelerated depreciation should be considered as one of the tools for tax incentives for innovation. After all, increased rates, or a reduced period of depreciation of fixed capital allow you to use fixed assets to calculate the amount of depreciation, which reduces the tax base in the new 
tax period. In essence, accelerated depreciation involves a reduction in income tax liabilities. However, in practice, the benefits that an enterprise receives from innovation are not significant. But this tool affects investment activity in public-private partnership, because the increased depreciation rates or its reduced term make it possible to increase in each tax period the use of fixed assets to calculate the amount of depreciation, which leads to a decrease in the object of taxation. As a rule, there are the following methods of operation of the mechanism of accelerated depreciation:

1) reduction of depreciation against service life;

2) introduction of increased depreciation rates;

3) combined method, which involves a combination of the first and second tools.

Such tools have become widespread in countries such as: Belgium, Denmark, the Netherlands, Luxembourg, Portugal, the USA, Finland, France, Sweden, Japan.

The investment policy of the state is designed to attract additional financial resources that are necessary for the growth of innovation. In most cases, foreign direct investment in the innovation sphere has almost no barriers. In addition, a foreign investor is subject to requirements similar to domestic investors. The state should strive to improve the investment climate and the attractiveness of the domestic innovation sphere, which will be the basis for increasing the volume of both foreign and domestic investment. In general, it is appropriate to recognize that today in Ukraine there is a great need to attract investment, as well as new mechanisms and tools that can increase financial revenues should be introduced. In addition, we consider it necessary to use the experience of foreign countries, in particular Austria.

One of the most common mechanisms for stimulating innovation on the basis of publicprivate partnership is an investment tax rebate, which involves reducing the tax base by the amount of innovation costs that are capital in nature. An important issue in using this tool is to determine the time period during which the tax rebate should be granted. The outlined mechanism is widely used in Austria, Belgium, Great Britain, Italy, the Netherlands, and the USA.

Thus, promising tools to stimulate the growth of innovation, including those on the basis of publicprivate partnership, contain:

- introduction of investment tax credit. According to A. Sokolovskaya, it should be "7-15\% of the cost of new investments in production equipment" (Sokolovskaya, 2004);

- development of a new depreciation policy, which should promote the modernization of fixed assets; - reduction of taxable profit on the costs of research and development or research;

- exemption from taxation of profits resulting from the introduction of innovative activities, especially for start-ups, for a period not exceeding three years.

According to the degree of influence on the organization of public-private partnership, direct and indirect factors are distinguished. Thus, the first include those that affect the formation, construction, and operation of the organizational structure, namely:

- type of management structure;

- provision of necessary personnel and quality of labour resources;

- availability of necessary information;

- way of organizing the labour process;

- number and scale of implemented innovative projects;

- adaptability of the management system to possible changes.

Indirect factors affect the conditions of functioning and change of organizational structure and consist of:

- legislative policy of the state;

- labour migration;

- level of education in the country;

- personnel policy;

- international law;

Among the factors that affect the organization and functioning of PPP, it is advisable to outline internal and external. The latter include:

- structural changes in the national economy;

- state-building, economic and tax policy;

- features of investment policy;

- dynamics of the structure of public administration as a whole;

Internal factors are:

- mobility of PPP management;

- information and technological support of administrative units;

- dynamics of public administration structure in separate structural units.

\section{Conclusions}

In conclusion, public-private partnership in the innovation sphere is important for increasing the competitiveness of the Ukrainian economy, as it allows to promote the development and 
implementation of new knowledge, equipment or technology and thus acts as an important factor in achieving innovative security of the national economy. The advantage of the partnership is the cooperation of public authorities, private business and science, which is intensified in order to find ways to implement certain tasks for innovative development of society as a whole.

The organization of public-private partnership, including in the field of innovation, considers numerous factors: institutional, legislative, economic, internal and external, direct and indirect. Their analysis allows us to state the need to improve the regulatory framework, which is designed to regulate such relationships, which will promote the development of innovative technologies. To this end, it is advisable to actively work towards the development and adoption of several relevant legislations and seek to use the positive experience of Western countries to promote public-private partnerships in innovation. In addition, significant attention should be paid to reforming institutional factors to intensify public-private partnerships in Ukraine.

The outlined factors are designed to promote a more effective organization of public-private partnership in innovation, which in modern conditions is a necessary component of socioeconomic growth of the country. The intensification of public-private partnerships is the basis for the development and implementation of socially necessary innovation programs and projects, which are often unattractive or unaffordable for private business.

\section{References:}

Scientific and innovative activity of Ukraine (2020). Statistical collection. State statistics service of Ukraine. (in Ukrainian)

Rozum, H. M. (2017). Conceptual approaches for the formation of mechanisms of public administration innovative development of regions. Investment: practice and experience, vol. 20, pp. 90-92. (in Ukrainian)

Varnavskyi, V. H. (2005). Public-private partnership: Forms, Projects, Risks / RAN. Moskva: Science. (in Russian)

Mihai, N. B. (2020). Public-private partnership in the field of innovation: foreign experience and domestic realities. Scientific notes of TNU named after V. I. Vernadsky. Series: Economics and Management, vol. 31(70), no. 1, pp. 52-59. (in Ukrainian)

On Public-Private Partnership: Law of Ukraine of July 1, 2010 No. 2404-VI. Verkhovna Rada Ukrainy. Available at: https://zakon.rada.gov.ua/laws/show/2404-17 (accessed 17 June 2020).

Danilov, A. D. (2009). Financial instruments of socio-economic development of the state and regions. Kyiv: Computerpres. (in Russian)

Marchenko, O., \& Tkachenko, V. (2003). Directions of tax stimulation of innovative activity of enterprises. Economist, vol. 1, pp. 13-17. (in Ukrainian)

Ivanov, Yu. B. (2007). Problems of development of tax policy and taxation: monograph. Kharkiv: VD "Inzhek". (in Ukrainian)

Sokolovskaya, A. M. (2004). The tax system of the state: theory and practice of formation. Kyiv: Knowledge Press. (in Ukrainian) 